\title{
PENGEMBANGAN \\ KUALIFIKASI DAN PERAN-PERAN PELAYAN \\ HAMBA TUHAN
}

\section{Hadi P. Sahardjo \\ ABSTRAK}

Tugas sebagai seorang hamba Tuhan adalah pelayanan yang sangat spesifik dan unik, oleh karena melibatkan seluruh aspek kehidupannya, baik aspek spiritual, emosional, fisikal, psikologikal, intelektual maupun sosial. Itulah sebabnya maka seorang hamba Tuhan harus senantiasa mampu mengembangkan kualifikasi dan peran-perannya selaku pelayan Tuhan dan umat-Nya. Tanpa itu semua maka pelayanan yang dilakukannya hanya akan nampak berhasil secara luar, tetapi sebenarnya tidak berkualitas sebagaimana yang diharapkan oleh Tuhan Yesus. Oleh karena itu tekad untuk terus mengembangkan diri menjadi sebuah keniscayaan.

Tugas dan pelayanan hamba Tuhan adalah pekerjaan Tuhan sendiri melalui tangan manusia yang dipanggil untuk melayani-Nya. Karena itu seorang hamba Tuhan dalam menjalankan tugas pelayanannya harus mau meningkatkan keterampilannya dalam segala bidang. Lebih daripada itu seorang hamba Tuhan harus memiliki kesiapan untuk melayani secara fulltime, full-life dan full hearted.

Kata-kata kunci: Hamba Tuban, pelayanan, spesifik, kualifikasi, peran, kualitas, keterampilan, keniscayaan.

\section{PENDAHULUAN}

Pada umumnya gereja-gereja mengharapkan agar hamba Tuhan yang melayani di gerejanya adalah orang yang serba bisa, mampu melakukan apa saja dan tanpa cacat. Ini adalah harapan ideal gereja terhadap hamba Tuhannya. Tetapi permasalahannya adalah, apakah ada hamba Tuhan yang bisa seperti itu? Untuk menjadi sempurna, jelas tidak mungkin. Namun jikalau tidak ada, apakah lalu tidak diperlukan upaya penuntutan dari hamba Tuhan itu sendiri terhadap hal tersebut? Dengan menyadari tugas panggilannya sebagai hamba Tuhan, maka sudah seharusnya apabila para hamba Tuhan terus meng-up grade dirinya. Hal itu tentunya tidak bisa terjadi begitu saja, tanpa mau mengenali dirinya terlebih dahulu. Berikut ini akan 
kita pelajari beberapa pokok yang berkaitan dengan diri gembala sebagai pemimpin, sekaligus tanggung jawab apa saja yang mesti dilakukannya.

Hamba Tuhan adalah manusia biasa yang memiliki banyak kelemahan dan kekurangan. Tetapi oleh karena dia menjadi pemimpin rohani bagi jemaat Tuhan, maka selain penyerahan diri dan panggilan Tuhan atas dirinya, dia juga harus membekali diri dengan berbagai macam kualifikasi yang dibutuhkan, baik yang bersifat natural, akademik maupun spiritualnya.

Robert D. Dale ${ }^{1}$ merumuskan tugas-tugas hamba Tuhan ke dalam tiga tugas pokok, yaitu: memberitakan (proclaim), memimpin (lead) dan memelihara atau merawat (care). Pertama, memberitakan meliputi: (i) pemberitaan firman Tuhan dari mimbar, (ii) memimpin ibadah, (iii) mengajar/pembinaan. Kedua, memimpin yakni (i) menjalankan tugas-tugas kepemimpinannya selaku gembala, (ii) memanej/mengatur hal-hal yang terkait dengan masalah organisatoris dan administrasi, sumber-sumber daya dan dana, dan yang ketiga, memelihara atau merawat, termasuk di dalamnya adalah (i) tugas-tugas pastoral (konseling) yang dilakukan di bawah atau di luar mimbar gereja serta (ii) mengembangkan bimbingan jemaat.

Dalam artikel ini secara lebih khusus hanya akan membahas tentang hal-hal yang berkaitan dengan peran-peran hamba Tuhan dalam pelayanannya.

\section{PERAN-PERAN HAMBA TUHAN \\ Peran Sebagai Pribadi}

Selaku manusia, seorang hamba Tuhan, tentu tidak bisa terlepas dari soal pribadinya. Karena pada kenyataannya justru sikap, perilaku dan kehidupan pribadinya sangat berpengaruh terhadap pelayanan dan kepemimpinannya. Robert C. Anderson' dalam bukunya yang berjudul 'The Effective Pastor" secara panjang lebar mengupas tentang karakter dan kepribadian seorang hamba Tuhan berdasarkan 1'Timotius 3:2-7; 2Timotius

${ }^{1}$ Robert D. Dale. Pastoral Leadership. (Nashville: Abingdon Press, 1986), 17-22.

2 Robert C. Anderson. The Effective Pastor (Chicago: Moody Press, 1985), 3-23. 
2:24 dan Titus 1:5-9. Dari ayat-ayat ini Anderson menyimpulkan ada 23 sifat atau karakter yang harus dimiliki oleh seorang hamba Tuhan atau pemimpin jemaat/pendeta/gembala sebagai berikut: (1) tidak bercacat, (2 suami dari seorang istri, (3) sabar, (4) bijaksana, (5) terhormat, (6) ramah, (7) mampu/cakap mengajar, (8) bukan pemabuk, (9) tak suka bertengkar, (10) lemah lembut, (11) pemurah, (12) tidak tamak uang, (13) mampu mengatur rumah tangga, (14) bukan seorang yang baru bertobat, (15) memiliki nama baik di luar gereja, (16) bukan pemarah/ pembenci/pendendam, (17) anakanaknya mengasihi Tuhan, (18) tidak angkuh, (19) bukan pemberang, (20) mencintai kebaikan, (21) suka berlaku adil, (22) saleh, dan (23) bisa mengontrol diri.

Tidak bercacat (1 Timotius 3:2; Titus 1:6-7).

Sebagai pribadi yang selalu dilihat oleh banyak orang, seorang gembala tidak bisa menyembunyikan diri atas segala perbuatan atau tingkah lakunya. Segala tingkah lakunya selalu diperhatikan orang. Jangankan berbuat suatu kesalahan, berbuat baik pun selalu mendapat kecaman atau kritik. Oleh karena itu seorang gembala perlu selalu mawas diri dan berhati-hati supaya hidupnya tidak bercacat agar tidak memberikan kesempatan bagi orang lain mencela kita. Orang tidak akan melihat gelar kita, kerajinan berkunjung sepanjang minggu, khotbahnya yang menarik setiap hari Minggu, dan sebagainya, tetapi yang dilihat adalah kehidupan kita. Apakah yang dikatakan (khususnya dalam khotbah) itu benar-benar sesuai dengan perbuatannya atau tidak. Secara tepat James Stalker dalam bukunya The Preacher and His Models, menuliskan sebagai berikut:

The great purpose for which a minister is settled in a parish is not to cultivate scholarship, or to visit the people during the week, or even to preach to them on Sunday, but it is to live among them as a good man, whose mere presence is a demonstration which cannot be gainsaid that there is a life possible on earth which is fed from no earthly source, and that the things spoken of in church on Sabath are realities. ${ }^{3}$

3 James Stalker, The Preacher and His Models (Grand Rapids: Baker Books House, 1967), 56. 
Suami dari seorang istri (1 Timotius 3:2; Titus 1:6)

Bahwa kekristenan menolak dan mencela perceraian itu sudah jelas. Jikalau jemaat atau kaum awam saja tidak boleh bercerai, apalagi hamba Tuhan. Janji perkawinan bahwa; “... akan hidup bersama setia sampai mati, baik dalam suka maupun duka...," harus dipertahankan. Tetapi kenyataannya bisa terjadi tidak demikian. Bagaimana jika perkawinannya ternyata tidak sebahagia seperti yang diharapkan? Disinilah akhirnya bisa terjadi penyelewengan. Mungkin tidak sampai bercerai atau berpoligami. Tetapi pada saat seorang hamba Tuhan mulai berpikiran untuk menyeleweng, apalagi ditindaklanjuti dengan tindakan yang nyata, maka ini sudah merupakan bentuk pengkhianatan perkawinan. Oleh karena itu Robert Anderson menasihati agar hamba Tuhan berjuang untuk menjauhkan diri dari segala macam godaan yang bisa merusak hubungan suami-istri. ${ }^{4}$

Dapat menahan diri (1 Timotius 3:2)

Alkitab terjemahan LAI baik TB maupun BIS menerjemahkan istilah Yunani $\nu \eta \phi \alpha \lambda \iota 0 \nu$ (nephalion; nefalion) yang berarti self controlled, yaitu mengontrol, menguasai atau mengendalikan diri. Tindakan ini terutama terkait dengan soal pengenda-lian hawa nafsu kedagingan. Seorang hamba Tuhan yang memiliki gaya hidup dan selera tinggi dalam berpakaian, mobil/kendaraan, makanan dan sebagainya bisa menjadikannya batu sandungan bagi jemaatnya. Kalau mau hidup mewah, sebaiknya tidak usah menjadi hamba Tuhan. Tetapi juga tidak lalu berarti bahwa hamba Tuhan tinggal di gubuk di daerah kumuh, sementara jemaatnya banyak yang tinggal di daerah elit. Namun sudah seharusnya seorang hamba Tuhan belajar hidup sederhana. Lebih baik dengarkanlah nasihat Amsal ini:

Taruhlah sebuah pisau pada lehermu, bila besar nafsumu!

Jangan ingin akan makanannya yang lezat, itu adalah hidangan yang menipu.

Jangan bersusah payah untuk menjadi kaya, tinggalkan niatmu ini.

Kalau engkau mengamat-amatinya, lenyaplah ia, karena tiba-tiba ia bersayap, lalu terbang ke angkasa seperti rajawali". ${ }^{5}$

${ }^{4}$ Robert Anderson. The Effective Pastor..., 6.

${ }^{5}$ Amsal 23:2-5 
Bijaksana (1 Timotius 3:2; Titus 1:8)

Bijaksana disini artinya adalah bertindak hati-hati (prudent) atau "menggunakan akal sehat" (sensible) yang dalam Bahasa Yunaninya adalah soofrona, $\sigma \omega \phi \rho o \nu \alpha$. Seorang hamba Tuhan jangan bertindak serampangan, sembrono dan semau gue. Segala sesuatu sebelum bertindak atau berkata terlebih dahulu harus dipikirkan akibat yang akan ditimbulkannya. Jangan mengikuti emosi dan "kata hati" sendiri.

Terhormat (1 Timotius 3:2)

Bahasa Indonesia menerjemahkan menjadi "sopan" yang sebenarnya juga bisa "teratur" diterjemahkan dari Bahasa Yunani "kosmion", коб $\mu \iota \nu$. Perilaku sopan (lawan dari tidak senonoh) dan hidup yang teratur akan menjadikan hamba Tuhan itu dihormai bukan saja oleh jemaatnya, tetapi juga oleh masyarakat.

Ramah (1 Timotius 3:2; Titus 1:8)

Atau "suka memberi tumpangan". Alkitab mengindikasikan bahwa seorang hamba Tuhan mesti suka memberi tumpangan (hospitable, philokhenon / filokenon $=\phi\llcorner\lambda o \chi \epsilon \nu O \nu)$ atau menyambut tamu. Itu berarti bahwa ia bersama istrinya harus merelakan sebagian kamarnya untuk menyambut tamu yang mungkin menginap serta menjamunya. Matius 10:13,14 dsb.

Mampu/cakap mengajar (1Timotius 3:2; 2Timotius 2:24)

Banyak yang menginterpretasikan hal ini secara salah. Supaya bisa mengajar, maka banyak pendeta atau hamba Tuhan yang setiap harinya menghabiskan waktunya selama berjam-jam untuk belajar atau membaca buku. Ini tentu bagus, tetapi belum tentu berguna untuk pelayanannya. Yang penting adalah, apakah hal ini aplikabel dalam pelayannya? Bukan sekedar teoretis, tetapi praktis? Yang penting adalah mengajar melalui kehidupan dan bukan hanya dengan ucapannya. Ingat! Tuhan Yesus dalam pengajaran-Nya selalu memberikan contoh atau teladan melalui perbuatan-Nya. Dia mengajar untuk saling melayani, dan Dia sendiri melakukan hal itu. Dia mengajarkan agar saling mengasihi, dan hal itu telah dilakukan-Nya. Ucapan- 
Nya selalu selaras dengan perbuatan-Nya (Yohanes 13:1-20; 15:9-17; Filipi 2:1-11)

Bukan pemabuk (1 Timotius 3:3; Titus 1:7)

Jangan dikira bahwa tidak ada pendeta yang masih suka minum minuman keras. Bahkan konon ada pendeta yang sebelum naik ke mimbar untuk berkhotbah harus "minum" terlebih dulu. Tujuannya adalah supaya dia memiliki semangat dan keberanian (yang semu) dan bukannya minta hikmat dan pimpinan Rohkudus. Bagaimanapun, minum minuman keras tidaklah mencerminkan kekudusan seorang hamba Tuhan.

Tidak suka bertengkar (1 Timotius 3:3; Titus 1:7)

Ada Hamba Tuhan yang hobinya bertengkar, baik dengan sesama hamba Tuhan maupun dengan jemaatnya. Tidak bisa cocok dengan siapa pun. Orang lain di matanya selalu dalam posisi yang salah. Meskipun sebenarnya dia sendiri yang bersalah, tetapi karena kepintarannya dia bisa memutar balik sedemikian rupa sampai akhirnya "sepertinya" orang lain yang memang bersalah. Dia juga merasa bangga setiap kali habis "mengalahkan" orang lain dalam pertengkaran itu. Dia selalu menganggap dirinya benar dan pantas menang, sementara orang lain selalu dianggap salah dan dikalahkan.

Lemah lembut (1 Timotius 3:3; 2 Timotius 2:24)

Menurut Tuhan Yesus, orang yang lemah lembut adalah orang yang berhak mewarisi bumi (Matius 5:5). Orang yang tidak suka bertengkar, banyak orang yang menyayangi. Banyak orang yang simpati, dan juga memberi.

Pemurah (1Timotius 3:3; 2Timotius 2:24)

Orang yang pemurah, suka memberi dan suka menolong, memberi tumpangan, akan diberkati Tuhan. Orang yang seperti ini oleh Tuhan Yesus disamakan dengan berbuat untuk Tuhan Yesus sendiri. Itulah sebabnya maka Tuhan Yesus mengatakan: “... ketika Aku lapar, kamu memberi Aku makan; ketika Aku haus, kamu memberi Aku minum; ketika Aku seorang asing, kamu memberi Aku tumpangan; ketika Aku telanjang, kamu memberi 
Aku pakaian; ketika Aku sakit, kamu melawat Aku; ketika Aku dalam penjara, kamu mengunjungi Aku” (Matius 25:35,36).

Tidak tamak akan uang (1Timotius 3:3; Titus 1:7)

Ada hamba Tuhan yang melayani motivasi pelayanannya tidak benar. Seringkali hanya karena uang. Ia sibuk pelayanan kesana-kemari, tetapi dengan tujuan untuk mengumpulkan banyak uang. Kadang-kadang ia membatalkan pelayanan yang sudah disepakatinya kalau ada pelayanan yang dinilainya bisa memberikan amplop yang lebih tebal. Hamba Tuhan semacam ini sebenarnya tidak melayani Tuhan, tetapi melayani dirinya sendiri. Oleh karena itu baginya tidak menjadi masalah kalau ia harus sering berpindah "ladang" baru yang penting bisa lebih "menjamin" masa depan kehidupannya. Uang telah menjadi nomor satu, sementara Tuhan menjadi nomor dua. Pelayanannya selalu diukur dan dihitung dengan uang. Hamba Tuhan seperti ini pada akhirnya pasti tidak akan dipakai oleh Tuhan.

Mampu mengatur rumah tangga (1 Timotius 3:4)

Banyak hamba Tuhan yang keliru dalam memahami pengertian tentang "mengutamakan Tuhan". Mereka beranggapan bahwa mengutamakan Tuhan berarti menomorduakan keluarga atau yang lainnya. Semua tetap harus dinomorsatukan. Jangan ada yang diabaikan. Untuk ini dibutuhkan hikmat dari Tuhan, supaya dalam melayani Tuhan kita tidak lalu mengabaikan keluarga. Banyak keluarga hamba Tuhan yang akhirnya berantakan, tidak terdapat keharmonisan rumahtangga karena merasa diabaikan oleh suami/ayah yang adalah hamba Tuhan. Banyak keluarga hamba Tuhan yang tidak bisa dijadikan contoh oleh jemaatnya. Padahal seharusnya tidak demikian.

\section{Bukan seorang yang baru bertobat (1 Timotius 3:6)}

Jika orang masih baru bertobat, tentu pemahaman dan pengenalan iman kekristenannya masih belum banyak dan mendalam. Ia mungkin memiliki kasih dan semangat yang berkobar-kobar. Tetapi jika ia adalah orang yang baru bertobat, maka ia belum matang untuk menjadi seorang pemimpin rohani. Kadang-kadang pemahaman teologi atau cara menafsirkan firman Tuhan masih ngawur. Itulah sebabnya biasanya persyaratan seorang calon 
mahasiswa sekolah teologi harus sudah menjadi jemaat di suatu gereja atau sudah dibaptis/sidi sekurang-kurangnya dua tahun. Selain itu juga untuk menghindari perasaan tinggi hati atau merasa diri "lebih" apabila orang itu baru bertobat.

\section{Memiliki nama baik di luar gereja (1 Timotius 3:7)}

Kadang-kadang jemaat tidak bisa mengetahui keadaan hamba Tuhannya di luar gereja. Mungkin di gereja dia kelihatan baik, menyenangkan, tetapi di luar gereja tidak memberikan kesaksian yang baik, bahkan menjadi batu sandungan bagi orang lain (Ingat, ada hamba Tuhan yang di gerejanya menjadi teladan rohani yang sangat baaik, tetapi di luar gereja ternyata dia suka main perempuan).

\section{Bukan pemarah/pembenci/pendendam (2 Timotius 2:24)}

Hamba Tuhan yang seperti ini sebenarnya sama dengan memasang jerat bagi dirinya sendiri. Dia akan mengalami kesulitan dari sifat buruknya ini. Hamba Tuhan yang tidak bisa mengampuni, selalu menaruh perasaan benci dan dendam, justru ia sendiri yang menderita, bukan orang yang dibencinya. Yang tidak bisa tidur nyenyak bukannya orang yang dibenci, tetapi justru dirinya sendiri, karena seperti selalu ada bara api di dalam dirinya.

\section{Anak-anaknya mengasihi Tuhan (Titus 1:6)}

Ingat pameo yang seringkali diucapkan seperti, "kebanyakan anak hamba Tuhan itu nakal"? Mungkin kita tidak suka dengan hal ini. Tetapi kenyataannya memang banyak hamba Tuhan yang seperti itu. Mengapa? Karena banyak hamba Tuhan yang tidak memerhatikan pendidikan dan kerohanian anak-anaknya. Atau bahkan sering tidak menjadi teladan yang baik bagi anak-anaknya. Tetapi seorang anak hamba Tuhan, seharusnya dia juga belajar untuk mengasihi Tuhan. Karena Tuhan memanggil tidak hanya ayahnya selaku pendeta/hamba Tuhan, melainkan panggilan itu ditujukan bagi seluruh anggota keluarganya.

Tidak angkuh (Titus 1:7) 
Orang ini selalu merasa diri lebih pandai, lebih hebat dari orang lain. Akibatnya apabila ada orang lain yang melebihi dirinya, ia akan berusaha dengan berbagai cara untuk menjegal dan "menenggelamkan" orang/hamba Tuhan lainnya. Ia selalu membandingkan orang lain dengan dirinya. Cenderung meremehkan orang lain. Ia juga tidak mau mengakui prestas, kelebihan dan ide-ide orang lain, tetapi secara diam-diam ia akan melakukan dan menganggapnya sebagai idenya sendiri.

\section{Bukan pemberang (Titus 1:7)}

Termasuk kategori ini adalah orang yang gampang marah dan tersinggung, tidak mau mendengarkan saran/kritik orang lain. Saran/kritik yang ditujukan kepadanya selalu ditanggapi secara negatif. Sering mencaricari kesalahan orang lain, yang banyak kali berujung pada pertengkaran.

\section{Menyintai kebaikan (Titus 1:8)}

“... suka memberi tumpangan, suka akan yang baik, bijaksana, adil, saleh, dapat menguasai diri.." Jelas, dan memang harus demikian.

\section{Suka berlaku adil (Titus 1:8)}

Adil tidak selalu berarti sama rata. Adil berarti objektif dan proporsional. Jangan menahan hak orang lain yang memang menjadi haknya. Seringkali orang tidak bisa melihat orang lain senang, sehingga ia menahan atau mengurangi haknya. Bukan oleh karena orang lain mendapat lebih banyak/lebih besar (misalnya gaji, berkat, dll), tetapi tidak mau kalau orang lain itu menikmati kebahagiaan.

Saleh (Titus 1:8)

Jelas. Ingat arti reverend. Hamba Tuhan yang tidak menuntut hidup saleh/suci, maka ia akan menjadi seperti "gong yang gemerincing" atau “tong kosong yang berbunyi nyaring”. Dalamnya tidak ada apa-apa, tetapi kelihatannya hebat. Kalau pun ia bisa berkhotbah hebat, itu bukan berasal dari pancaran hatinya, melainkan hati dari akal/otaknya. Ia tidak akan menjadi teladan rohan yang baik. Meditasi pribadi, membaca firman Tuhan dan berdoa harus menjadi kebutuhan hidupnya setiap hari. 


\section{Bisa mengontrol diri (Titus 1:8)}

Mengontrol diri dalam berbagai hal. Ia harus tahu posisi dan statusnya. Seorang hamba Tuhan harus selalu meminta hikmat dan kebijaksanaan dari Roh Kudus, supaya apapun yang dilakukannya selalu dikontrol dan dipimpin oleh-Nya. Jadilah teladan dan jangan jadi batu sandungan.

Tentu saja sebagai hamba Tuhan tidak boleh merasa cukup puas jika merasa telah memiliki "sebagian" atau "beberapa" dari kriteria yang disebutkan di atas. Ini adalah kriteria baku yang harus dimiliki dan dituntut oleh setiap hamba Tuhan. Memang, untuk bisa memenuhi seluruh kriteria seperti itu bukan persoalan yang gampang. Tetapi yang jelas harus ada penuntutan, seperti yang dikatakan oleh Tuhan Yesus dalam salah satu bagian khotbah-Nya di atas bukit, "Karena itu haruslah kamu sempurna sama seperti Bapamu yang di surga adalah sempurna (Matius 5:48).

Lebih lanjut Anderson mengatakan bahwa setiap pemimpin/gembala harus memiliki panggilan Allah yang unik terhadap dirinya untuk melayani (Yesaya 6). Dalam hal ini konsekuensinya adalah: (a) harus siap sedia untuk melayani, (b) siap melakukan semua persyaratan tersebut di atas tanpa reserve dan yang tidak kalah penting, (c) ia harus yakin dengan mengatakan pada diri sendiri bahwa ia bisa dan mampu berkomunikasi dengan baik terhadap orang-orang yang dilayani. ${ }^{6}$ Bertolak dari sini dapat dirumuskan bahwa ada banyak hal penting yang harus diperhatikan oleh seorang pemimpin jemaat agar bisa menjadi pemimpin yang baik, yang semakin "serupa" dari segi kepribadian/karakter, kemampuan, moral dan kerohanian serta dedikasinya dalam pelayanan.

Pertama, soal panggilannya. Panggilan untuk menjadi hamba Tuhan atau pendeta sering diungkapkan dengan berbagai macam ungkapan atau cara. Ada yang mengatakan bahwa mereka mendapat panggilan langsung dari Tuhan dengan suara-Nya yang dapat didengar (audible voice). Sebagian lagi mengatakan bahwa mereka mendapat panggilan itu melalui mimpi atau pengalaman-pengalaman yang bersifat supranatural. Ada lagi yang

6 Robert C. Anderson, The Effective ..., . 20-21. 
mengatakan bahwa Allah memanggilnya melalui sebuah visi khusus. Tapi ada juga yang mengatakan bahwa mereka mendapat panggilan yang sama dengan orang-orang lain pada umumnya, hanya saja mereka mau merespons panggilan itu dengan suatu komitmen untuk "menyerahkan diri" dan bersandar kepada Tuhan supaya bisa melayani. Tapi pada kenyataannya memang banyak orang yang kurang mengenal dengan jelas bagaimana Tuhan telah memanaggilnya untuk melayani. ${ }^{7} \mathrm{Hal}$ ini menyatakan bahwa pengalaman panggilan setiap orang itu berbeda-beda. Panggilan Tuhan terhadap Musa untuk memimpin bangsa-Nya berbeda dengan panggilanNya terhadap Yesaya maupun Yeremia. Demikian pula panggilan-Nya terhadap Paulus berbeda dengan panggilan-Nya terhadap ke-12 murid Tuhan Yesus yang lain. Setiap orang memiliki panggilan yang unik. Thomas Curtis menyimpulkan, bahwa konsep alkitabiah tentang panggilan untuk melayani itu semestinya tidak memasukkan faktor visi, wahyu (ilham) khusus, atau pengalaman supranatural atau pengalaman mistis lainnya. Baginya, yang penting adalah:8 (1) Apakah ia telah benar-benar rela untuk "melepaskan" segala sesuatu—termasuk pekerjaannya — karena pelayanan yang akan dilakukannya? [Matius 4:18-22]; (2) Apakah ia memiliki kualitas sebagai orang yang injili dan alkitabiah? (3) Apakah ia memiliki karuniakarunia khusus yang diperlukan untuk melengkapi pelayanannya nanti? (4) Apakah para penatua dan gereja juga memiliki pikiran yang sama bahwa ia memang ada karunia khusus, memiliki bakat tertentu serta memiliki kualifikasi moral yang baik? (5) Apakah hidupnya sesuai dengan doktrin dan pengajarannya? (6) Apakah ia juga bersedia hidupnya dijadikan sebagai teladan atau contoh bagi domba-dombanya?

Kedua, dalam hal karakter. Karakter atau kepribadian hamba Tuhan sangat berpengaruh dalam pelayanannya. Sebagaimana telah dituliskan di atas, Rasul Paulus menegaskan hal ini berkaitan dengan prasyarat yang harus dimiliki oleh para calon pelayan Tuhan, dalam hal ini penatua dan diaken. Meskipun demikian hal ini juga berlaku am, untuk seluruh hamba Tuhan.

${ }^{7}$ Curtis C. Thomas, Practical Wisdom for Pastors (Crossway Books, Wheaton, Ill.:2004) . 20.

${ }^{8}$ Robert C. Anderson, The Effective ..., . 21. 
Kriteria-kriteria semacam inilah yang dibutuhkan. Di sini tidak akan diuraikan seluruhnya secara lengkap. David Hocking menegaskan bahwa faktor yang sangat penting yang tidak boleh tidak harus dimiliki oleh seorang hamba Tuhan atau pemimpin gereja adalah "dapat dipercaya. "9 Hal ini sangat tepat. Karena bagaimana mungkin seorang yang tidak bisa dipercaya, baik dalam perkataan dan karakter bisa menjadi seorang pemimpin yang baik?

Ketiga, berhubungan dengan moralnya. Seorang hamba Tuhan harus memiliki moral yang baik dan rela menjauhi kenistaan dosa (Roma 6) serta mau menuntut kehidupan kerohanian serta terus meningkat-kannya. Ted Engstrom $^{10}$ dan Hocking ${ }^{11}$ memberikan penekanan bahwa seorang hamba Tuhan harus selalu meningkatkan dirinya serta memiliki kehidupan moral yang baik. Itulah sebabnya Richard Foster mengingatkan para pemimpin, khususnya hamba Tuhan untuk berhati-hati terhadap 3 (tiga) jenis godaan utama yang sangat potensial bisa menjatuhkan hamba Tuhan, yaitu seks, uang dan kedudukan atau yang sering kita kenal sebagai 3TA, yaitu harta, takhta dan seksualitas. Kita tentu masih ingat kasus Pendeta Ted Haggard. Seorang pemimpin dari 40 juta kaum injili di Amerika. Dia juga salah seorang penasihat George W. Bush, Jr. dan termasuk salah seorang tim sukses pemilihan presiden untuk pencalonan Bush maju sebagai presiden pada periode keduanya. Dia sangat dicintai jemaat karena pelayanannya yang berhasil dengan khotbah-khotbah yang menarik. Memiliki seorang istri yang cantik dan tiga orang anak yang sudah menginjak remaja. Termasuk orang yang paling gencar menyatakan perlawanannya terhadap upaya memasukkan kaum gay ke dalam dinas kemiliteran Amerika. Pelayanannya di kalangan pelajar dan mahasiswa dan di penjara sangat berhasil. Tetapi dia jatuh dalam dosa seksual dengan seorang laki-laki gay. Tedd akhirnya jatuh. Jemaatnya menangisi dalam ketidakpercayaan akan kejatuhannya. Tapi ini sungguh

${ }^{9}$ David Hocking: Rahasia Keberhasilan Seorang Pemimpin. (Yogyakarta: Andi Offset, 1994) . 27 dyb.

${ }^{10}$ Ted W. Engstom, The Making of a Christian Leader. (Grand Rapids Michigan: Zondervan Publ. House, 1985) .12.

11 David Hocking, op. cit. . 28 
suatu kenyataan yang menyakitkan. Hamba Tuhan adalah juga manusia yang bisa jatuh dalam soal harta, kekuasaan dan seks. Karena itu harus waspada.

Keempat, dalam hal kerohaniannya. Thomas Curtis ${ }^{12}$ mengungkapkan pengalamannya bahwa setelah banyak disibukkan dengan pelayanan, maka ia seringkali mengalami kesulitan untuk terus bisa memelihara secara optimal persekutuan pribadinya (personal devotional) dengan Tuhan. Alasan logis pada umumnya adalah karena pelayanan pastoral-konseling yang memakan banyak waktu, pertemuan atau rapat-rapat yang seringkali harus sampai larut malam; kemudian masih harus menyiapkan khotbah, perkunjungan (pembezukan atau visitasi), penelaahan Alkitab, dsb. Sehingga alih-alih mendoakan jemaat, berdoa bagi diri sendiri saja kadangkala sudah tidak memiliki cukup waktu. Itulah sebabnya maka Richard Lowrence menegaskan bahwa-bagaimana pun-seorang hamba Tuhan sebagai pemimpin rohani harus memiliki kehidupan doa dan persekutuan dan penyembahan yang baik dengan Tuhan. Hal ini pada akhirnya akan dijadikan sebagai bekal dalam memimpin jemaatnya untuk melakukan hal serupa. Dengan dia sendiri memiliki kehidupan rohani yang baik, jemaatnya pasti juga akan terpengaruh dan meneladaninya ${ }^{13}$. Melalui kehidupan ibadah/persekutuan pribadinya yang baik dengan Tuhan, seorang pemimpin baru akan layak untuk memimpin dan mendorong jemaatnya melakukan hal yang sama. Karena begitu pentingnya hal ini, maka Grady Hardin ${ }^{14}$ merasa perlu untuk menuliskan buku khusus yang berjudul: "The Leadership of Worship" yang mengupas tentang kepentingan pray and worship serta bagaimana gembala itu memimpin, mengelola, menyelenggarakan dan hidup di dalam iklim seperti itu.

Kelima, dalam kehidupan doanya. Kita sering mendengar ungkapan bahwa "doa adalah nafas hidup bagi orang percaya". Hal ini menunjukkan bahwa doa merupakan bagian yang tidak terpisahkan dari kehidupan seorang

12 Thomas C. Curtis. Practical ..., . 21.

13 Richards O. Lowrence and Clyde Hoeldtke: Church Leadership: Following the Example of Jesus Christ (Grand Rapids, MI.: Zondervan Publishing House, 1988) 238.

${ }^{14}$ Grady Hardin. The Leadership of Worship. (Nashville: Abingdon Press. 1980) 15 dyb. 
hamba Tuhan, karena doa itulah yang memberikan kekuatan dan mendatangkan kuasa untuk tetap bisa melayani Tuhan yang memberikan kekuatan kepadanya (Efesus 6:18; Yakobus 5:16). Berdoa sebelum dan sesudah berkhotbah. Berdoa dalam persekutuan doa di gereja. Kita juga berdoa ketika sedang mengunjungi orang yang sedang sakit, baik di rumah maupun rumah sakit. Kita juga selalu berdoa dalam acara-acara ucapan syukur, bahkan dalam kegiatan-kegiatan yang bersifat "duniawi" sekalipun, kita juga berdoa. Misalnya dalam suatu kegiatan olah raga atau piknik, kita selalu mengawalinya dengan doa. Segala sesuatu selalu kita awali dan sertai dengan doa.

Dalam kehidupan sehari-hari di tengah-tengah masyarakat, kita mungkin dikenal sebagai orang yang suka berdoa. Tetapi bagaimana halnya dengan kehidupan pribadi kita. Apakah kita tetap bisa disebut sebagai orang yang suka berdoa (man of prayer)? Ini adalah suatu ujian yang berat. Kegiatan yang kita lakukan di depan jemaat atau publik hanyalah merupakan sesuatu yang berkaitan dengan tugas atau kewajiban kita. Sejauh mana dan bagaimana kita menggunakan waktu pribadi kita, hal itu akan menunjuk-kan integritas kerohanian kita. Curtis mengatakan bahwa doa pribadi kita itu pada akhirnya juga akan menunjukkan hubungan pribadi kita dengan Tuhan itu seperti apa. ${ }^{15}$

Seringkali kita jumpai dalam Alkitab bagaimana Allah berbicara dengan umat-Nya ketika mereka sedang berdoa. Allah menyatakan rencana dan kehendak-Nya atas permintaan Hana yang menganggapnya telah mandul dalam bentuk pengabulan doa dan jawaban langsung untuk memberinya seorang anak (1Samuel 1:1-28); atau Imam Zakharia sehingga Tuhan memberikannya seorang anak, Yohanes Pembaptis (Lukas 1:5-25); atau Kornelius dan Petrus yang dipertemukan Tuhan melalui doa pribadi mereka. Anak-anak Allah akan kehilangan hadirat Allah apabila dia telah kehilangan kehidupan doanya. Berdoa itu sangat penting sebagai sarana untuk "omongomong" dengan Tuhan. Saya sangat suka menggunakan akronim doa sebagai kependekan dari D-atang (untuk) O-mong-omong (dengan) A-llah.

15 Thomas Curtis, Practical ..., 23. 
Memang, ketika kita berdoa, sesungguhnya kita sedang berbicara atau omong-omong dengan Allah. Jadi dalam berdoa kita jangan hanya berbicara sendiri dengan mengajukan sederet daftar permohonan, tanpa memberikanNya kesempatan untuk berbicara kepada kita secara pribadi. Ini hanya bisa didapat dengan cara berdiam diri sejenak di hadapan Tuhan.

Keenam, reputasi dalam hal keuangannya. Seorang hamba Tuhan memang tidak seharusnya berurusan dengan soal uang. Mestinya prinsip, “... asal ada makanan dan minuman, cukuplah" (1Timotius 6:8) itu benar-benar bisa menjadi falsafah hidup seorang hamba Tuhan. Tetapi kadang-kadang seorang hamba Tuhan memang harus berhadapan dengan suatu realitas yang tidak bisa dihindari antara adanya kebutuhan, keadaan dan lingkungan sekitar. Suatu kondisi yang memang bisa menyebabkan seorang hamba Tuhan sekalipun menjadi bimbang. Belum kalau ada tuntutan dari keluarga — anak atau istrinya.

Thomas Curtis menuliskan, bahwa menurut beberapa perusahaan penjamin kredit di Amerika, yang paling banyak memiliki masalah dengan soal kredit adalah para pendeta dan para salesman perusahaan asuransi. Bahkan ada "joke" yang mengatakan bahwa pekerjaan atau profesi-profesi yang diawali dengan huruf "p" merupakan kelompok masyarakat yang paling banyak bermasalah dengan soal kredit dan hutang. Merekalah adalah para: pelukis (painter), polisi (policeman), politikus (politician) dan pendeta (preacher), yang secara nasional tercatat sebagai kelompok yang bereputasi paling buruk berhubungan dengan soal kredit. Sering macet atau bahkan tidak bisa membayar. ${ }^{16}$ Terlepas dari sejauh mana kebenaran laporan tersebut, namun paling tidak hal ini telah memberikan suatu gambaran kepada kita yang menunjukkan bahwa memang ada masalah dengan soal keuangan yang dihadapi para pendeta atau hamba Tuhan. Tengok saja apa yang pernah dialami oleh pengkhotbah televisi, Jim Baker, yang akhirnya dijebloskan ke jeruji besi karena soal uang. Atau masih ingat dengan Ongkowijoyo, yang juga harus dipenjarakan selama bertahun-tahun karena menipu uang masyarakat dengan dalih uang yang disimpan akan diberi bunga yang sangat

16 Thomas Curtis, ..., 27. 
besar? Bagaimana pun, hamba Tuhan itu ibarat ikan yang dimasukkan dalam aquarium, yang bisa dilihat oleh siapa saja tanpa kita bisa menyembunyikan diri. "Affair" keuangan kita akan selalu nampak dan dilihat dengan jelas serta terus dinilai oleh jemaat kita.

Ketujuh, gaya hidupnya. Sinclair Ferguson mengemukakan ada tiga hal utama yang harus dijadikan sebagai pola hidup oleh setiap orang Kristen, khususnya hamba Tuhan, yaitu: harus berjalan dalam kasih, berjalan dalam terang dan berjalan dalam hikmat ${ }^{17}$ (1) Secara positif dapat dikatakan bahwa berjalan dalam kasih berarti meneladani kasih Kristus yang dinyatakan di atas kayu salib. Ini berarti bahwa dalam kasih harus rela memberi diri bagi orang lain. Ferguson mengutip perkataan Martin Luther yang mengatakan bahwa masalah manusia yang utama adalah sibuk dengan dirinya sendiri (incurvatus in se). Di lain pihak, dari segi negatif, berjalan dalam kasih berarti keberanian untuk berkata "tidak" terhadap apa yang Allah juga katakan tidak. Itu berarti bahwa kita harus berani "menolak" jalan yang lain, pada saat kita memutuskan untuk berjalan bersama Allah. ${ }^{18}$ (2) Berjalan dalam terang memiliki beberapa ciri, yaitu keterpisahan dari dosa.

Jangan salah! Seorang hamba Tuhan dalam berpakaian akan menjadi sorotan jemaatnya. Kalau memakai pakaian dengan bahan yang mahal dengan penjahit atau desainer terkenal, pasti akan dipergunjingkan sebagai hamba Tuhan yang konsumtif dan maunya hidup mewah bak pengusaha. Apalagi jika mengenakan cincin berlian dan beberapa cincin lain yang menghiasi jari-jari tangannya. Kalau berkhotbah sepertinya sengaja memamerkan cincin-cincin mahalnya. Belum lagi kalau istri hamba Tuhan juga berbuat hal yang sama. Perhiasan yang bergelantungan di sana-sini. Di jari-jemari, pergelangan tangan, telinga dan di leher. Bahkan ada yang mengikuti tren memakai gelang pada pergelangan kakinya. Ini istri direktur atau istri hamba Tuhan? Ditambah lagi dengan mobil yang berkategori mewah, sehingga sama sekali tidak ada kesan sebagai hamba Tuhan yang

${ }^{17}$ Sinclair B. Ferguson. Menemukan Kehendak, Allah. (Momentum, Surabaya: 2003), 39 dyb.

18 Sinclair Ferguson, Menemukan ..., 43. 
harus rela menderita dan melayani umat-Nya. Saya pernah berjumpa dengan seorang hamba Tuhan dari salah satu gereja yang besar. Jemaatnya memang ribuan. Ketika saya memuji mobil barunya, lalu dengan bangga dan antusiasnya menceritakan bagaimana dia hampir setiap tahun menjual atau menukarkan mobilnya dengan mobil produk terbaru, meskipun mobilnya itu baru beberapa bulan dibelinya. Ada pula seorang hamba Tuhan yang selalu mencoba untuk "mencicipi" tidur di hotel yang baru diresmikan bersama dengan keluarganya, dengan alasan "yang penting sudah pernah mencoba dan marasakan menginap di hotel berbintang yang bagus." Wah, kalau demikian, ini namanya untuk kepuasan atau kebutuhan? Sangat mengenaskan!

Seorang hamba Tuhan seharusnya bisa menempatkan diri di tengah jemaatnya. Kalau seluruh jemaatnya memiliki tingkat kesejahteraan hidup di atas rata-rata, bolehlah seorang hamba Tuhan menampakkan gaya hidup yang agak "sedikit" mewah supaya kita bisa menempatkan diri bersama mereka. Tetapi jika ternyata masih banyak juga anggota jemaat yang kehidupannya pas-pasan, bahkan cenderung berkekurangan, maka apabila hamba Tuhan memiliki pola hidup yang demikian, hal itu justru hanya akan menyakiti hati mereka dan menjadikan batu sandungan. Hal ini sudah barang tentu akan menimbulkan jarak atau menciptakan gap antara gembala dengan dombanya. Antara pendeta dengan jemaatnya. Tentu saja seorang hamba Tuhan juga tidak boleh lalu bersikap terlalu ekstrem, sehingga mengenakan pakaian pun teramat sederhana-yang itu-itu saja-yang pada akhirnya justru akan memermalukan diri dan jemaatnya. Pernah suatu ketika saya menghadiri acara kebaktian penghiburan di tempat seorang yang cukup kaya dan terpandang. Pendeta yang berkhotbah mengenakan kemeja putih yang sudah kelihatan tua yang pada bagian sakunya ada bekas tinta. Dasi yang dikenakan pun berwarna hitam yang warnanya sudah memudar, berukuran kecil, mungkin peninggalan kakeknya. Akhirnya sepanjang khotbahnya itu banyak orang yang ngrasani (menggosipi) hamba Tuhan tersebut yang seakanakan sengaja memberitahukan keadaannya kepada tuan rumah atau jemaat yang hadir. Padahal saya tahu hamba Tuhan tersebut melayani di sebuah gereja yang cukup baik. Boleh sederhana, tetapi jika menampakkan diri terlalu sederhana, padahal sebenarnya dia bisa tampil lebih baik, maka hal itu 
pada akhirnya justru akan memermalukan Tuhan dan dirinya sendiri. Almarhum dosen saya, Pendeta Mattew Sie, yang mengungkapkan motto hidup pelayanannya dengan kalimat singkat, "Simplicity is the way of my life". Ini memang sesuai dengan gaya hidupnya yang sederhana, tetapi tidak memermalukan Tuhan.

Seorang hamba Tuhan memang jangan sampai menonjolkan kekayaan dan kemewahannya sehingga jemaat tidak berani mendekatinya, sebaliknya juga jangan terlalu menunjukkan kemiskinannya agar mendapatkan simpati jemaat tetapi akhirnya justru direndahkan dan memermalukan Tuhan maupun dirinya sendiri. Tepat sekali nasihat Amsal yang demikian, "Supaya, kalau aku kenyang, aku tidak menyangkal-Mu dan berkata: Siapa TUHAN itu? Atau, kalau aku miskin, aku mencuri, dan mencemarkan nama Allahku." (Amsal 30:9).

Ketika Paulus berkata, "Jadilah pengikutku, sama seperti aku juga menjadi pengikut Kristus," (1Korintus 11:1), atau "... ikutilah teladanku dan perhatikanlah mereka, yang hidup sama seperti kami yang menjadi teladanmu." (Filipi 3:17), atau "Sebab itu aku menasihatkan kamu: turutilah teladanku!" (1Korintus 4:16); hal ini jelas menunjukkan bahwa karena orientasi kehidupan Paulus itu bersumber dan berdasar pada Kristus, maka ia berani mengucapkan kalimat demikian. Pernyataannya, "Ikutilah teladanku" atau "Jadilah pengikutku ..." itu pantas diucapkannya karena memang ia sudah terlebih dahulu menjadi pengikut Tuhan Yesus secara sungguh-sungguh serta telah meneladani-Nya secara tepat. Oleh karena itu Paulus tidak sekedar berbicara, tapi dia sendiri telah melakukannya. Dia telah membuktikan itu ketika dia berkata, "Tetapi apa yang dahulu merupakan keuntungan bagiku, sekarang kuanggap rugi karena Kristus. Malahan segala sesuatu kuanggap rugi, karena pengenalan akan Kristus Yesus, Tuhanku, lebih mulia dari pada semuanya. Oleh karena Dialah aku telah melepaskan semuanya itu dan menganggapnya sampah, supaya aku memeroleh Kristus." (Filipi 3:7-8). Hal ini berbeda dengan banyak orang yang seringkali melontarkan pernyataan, "Ikutilah apa yang saya katakan, dan bukan apa yang saya lakukan!". Pernyataan ini bersifat mendua, karena tidak sinkron antara perkataan dan perbuatan. Ini sangat berbeda dengan Tuhan Yesus 
dan yang kemudian diikuti oleh Paulus. Di sini ada kesamaan antara apa yang dikatakan dengan apa yang dilakukan. Seharusnya memang demikianlah sikap hidup orang Kristen, lebih-lebih sebagai hamba Tuhan. Pernyataan Paulus ini dapat kita pakai sebagai cermin diri dan gaya kepemimpinan kristiani yang sejati.

Kedelapan, dalam komitmennya. Seorang hamba Tuhan terlebih dahulu harus memiliki komitmen yang sangat kuat terhadap persembahan hidup pelayanannya. Komitmen ini berhubungan dengan janji, sebagaimana Allah berjanji dengan diri-Nya sendiri dengan janji berith, yaitu janji yang takkan dibatalkan dengan dalih dan dengan cara apa pun. Janji itu harus dipegang teguh dan ditepati. Demikian pula dengan komitmen. Orang yang memiliki komitmen harus berusaha "sekuat tenaga" untuk bisa melakukannya sesuai dengan komitmen yang telah dibuatnya. Jadi jangan main-main dengan komitmen yang telah Anda buat. Bruce P. Powers ${ }^{19}$ menuliskan beberapa komitmen yang harus dimiliki oleh seorang pemimpin, yaitu: komitmen untuk pelayanan, komitmen terhadap misi dan komitmen terhadap hubungan (relationship) nya baik dengan Allah maupun dengan sesama manusia. Tanpa komitmen semacam itu, pelayanan dan kepemimpinannya patut dipertanyakan.

Charles Swindol, ${ }^{20}$ dalam bukunya, "Improving Your Serve" mengatakan bahwa berpegang teguh pada komitmen-apa pun itu-merupakan hal yang mahal. Maksud Swindol sangat jelas. Untuk tetap memertahankan komitmen, diperlukan pengorbanan plus usaha, dan itu penting. Karena dengan komitmen, berarti kita telah mengikatkan diri pada komitmen kita, sehingga apabila kita tidak melaksanakannya, maka berarti kita telah melawan diri kita sendiri. Komitmen lebih dari sekedar janji, tetapi dia lebih dekat pada berith, yang harus ditepati. Jerry Bridges ${ }^{21}$ lebih menekankan lagi,

19 Bruce P. Powers. Christian Leadership. (Nashville: Broadman Press, 1979), 11-13.

${ }^{20}$ Charles Swindol, Improving Your Serve (Pioner Jaya, Bandung: 2005), 59.

${ }^{21}$ Jerry Bridges. The Discipline of Grace (Pionir Jaya, Bandung: 2007), 163. 
agar setiap hamba Tuhan memiliki disiplin dalam komitmennya (Mazmur 119:106).

\section{Peran dalam Keluarga}

\section{Memberikan peran yang tepat kepada istri.}

Hikmat Allah tidak pernah berubah. Dia tahu apa yang kita butuhkan. Setiap hari dalam hidup kita ini memerlukan adanya penolong. Untuk itu Tuhan memberikan seorang "penolong yang sepadan". Sehingga pada saat kita merasa tersendiri, frustrasi dan menghadapi banyak tugas atau pelayanan, ada pribadi yang bisa menolong kita. Dalam hal ini para istri atau pasangan hidup kitalah yang bertindak sebagai penolong itu. Dia bisa bertindak sebagai konselor sekaligus pengritik bagi kita. Sesungguhnya para istri telah melakukan perannya yang sangat unik. Ia yang paling mengerti kita, mencintai kita. Hanya dia yang bisa berbicara secara terbuka dengan kita. Tentu saja ia akan sangat sedih dan kecewa kalau kita jatuh, tetapi sebaliknya akan merasa bangga dan bahagia jika kita berhasil. Oleh karena itu hidup, rencana, kesempatan-kesempatan, bahkan ketakutan, frustrasi dan relasi kita di luar rumah perlu dibuka di hadapan istri. Memang harus diakui, bahwa dalam banyak hal, para istri telah menjadi berkat yang luar biasa bagi para hamba Tuhan, karena mereka dalam posisinya yang sangat unik telah membantu kita yang tidak bisa digantikan oleh orang lain.

Tentu bukan merupakan suatu kebetulan jika Tuhan memakai hubungan antara suami dan istri itu untuk menganalogikan serta merepresentasikan relasi-Nya dengan gereja (Efesus 5:22-23). Dengan menggunakan analogi itu sebenarnya Ia telah mengajar para suami agar kita peduli dan membela para istri. Mereka-para istri-harus mendapatkan tempat dan penghargaan yang layak karena peran besarnya dalam menyokong keberhasilan pelayanan kita.

\section{Menjaga keharmonisan dalam keluarga}

Seorang hamba Tuhan harus bisa mengatur rumah tangganya (1Timotius 3:4). Seorang hamba Tuhan harus memerhatikan hal ini. Alasan kesibukan dan keterbatasan waktu tidak boleh dipakai sebagai dalih untuk 
tidak memerhatikan keluarganya. Ia harus memerhatikan kebersamaan dengan keluarganya. Harus bisa membagi antara pelayanan dengan keluarganya. Jangan karena pelayanan maka keluarga lepas dari perhatian. Misalnya menjadikan makan malam sebagai kesempatan berkumpul bersama keluarga. Ada seorang hamba Tuhan yang saya kenal baiki, di tengah kesibukan pelayanannya sebagai pengajar, konselor sekaligus gembala, selalu menjadikan hari Sabtu sebagai "hari keluarga" di mana dia tidak pernah mau menerima pelayanan pada akhir pekan. Hari-hari itu selalu diisi dengan acara bersama dengan istri dan anak-anaknya. Entah makan-makan atau sekedar jalan-jalan. Robert Anderson menganjurkan, bahwa dengan adanya pelayanan yang padat seperti itu maka yang paling penting sekarang adalah harus bisa menjaga kualitas kebersamaan dengan keluarga. Karena istri dan anak-anak itu merupakan pendukung utama yang menunjang keberhasilan pelayanannya ${ }^{22}$. Hal senada juga dikatakan oleh David Hocking ${ }^{23}$ bahwa kebersamaan dengan keluarga itu merupakan suatu kebutuhan dan sangat penting dalam kehidupan seorang pelayan.

\section{Menjadikan kehidupan keluarga sebagai contoh}

Kehidupan keluarga hamba Tuhan sering menjadi sorotan. Celakanya, memang banyak kehidupan keluarga hamba Tuhan yang justru tidak bisa dijadikan sebagai panutan. Dari diskusi kelas yang saya ajar terungkap, dan ini tidak bisa dipungkiri, bahwa banyak hamba Tuhan yang justru gagal mendidik anaknya sendiri menjadi anak yang baik. Lalu di mana fungsi keteladanan? Seorang pemimpin / gembala seharusnya mampu membina dan menjaga kehidupan keluarganya secara harmonis. Hal ini penting karena akan bisa menjadi contoh yang hidup / konkret bagi yang dipimpinnya. Seorang pemimpin/hamba Tuhan yang baik harus menjadi ayah atau suami yang baik, bertanggung jawab, dan mengasihi anak-istrinya. Keluarga hamba Tuhan yang seperti ini akhirnya akan dijadikan sebagi model oleh jemaatjemaatnya. Sebagaimana telah dipaparkan di depan, dalam kaitannya dengan

${ }^{22}$ Robert C. Anderson. The Effective Pastor: A Practical Guide to Ministry. (Chicago: Moody Press, 1990) 68, 93.

23 David Hocking, op. cit. 15. 
hal ini rasul Paulus kembali menegaskan, "Karena itu penilik jemaat haruslah seorang yang tak bercacat, suami dari satu isteri, dapat menahan diri, bijaksana, sopan, suka memberi tumpangan, cakap mengajar orang, bukan peminum, bukan pemarah melainkan peramah, pendamai, bukan hamba uang, seorang kepala keluarga yang baik, disegani dan dihormati oleh anakanaknya" (1Timotius 3:2-4).

\section{Menjadi pemimpin dalam mezbah keluarga.}

Banyak keluarga Kristen yang menikmati kehangatan suasana kehidupan yang harmonis dalam melalui persekutuan atau mimbar keluarga. Tapi tak jarang pula yang selalu mengalami kegagalan untuk menciptakan kondisi semacam itu.

Dalam mezbah atau persekutuan keluarga itu juga bisa digunakan untuk saling berbagi pengalaman (sharing) dan mendoakan. Di situ orang tua bisa menyampaikan pesan-pesan khususnya kepada anak-anak. 'Dan kamu, bapabapa, janganlah bangkitkan amarah di dalam hati anak-anakmu, tetapi didiklah mereka di dalam ajaran dan nasihat Tuhan' (Efesus 6:4). Memang benar, bahwa keluarga juga memerlukan waktu untuk refresing, melewatkan sedikit waktu untuk jalan-jalan bersama atau makan di luar. Tapi jangan sampai agenda semacam itu terlalu dipentingkan sehingga melalaikan kegiatan yang dianggapnya rutin. Di mana dan kapan pun kehadiran Tuhan dalam keluarga kita itu sangatlah penting, seperti pentingnya keluarga itu sendiri dalam kehidupan hamba Tuhan. Secara ekstrem, Curtis Thomas mengatakan bahwa keluarga, yaitu istri dan anak-anak itu sangat dan paling penting bagi hidupnya. Mereka harus mendapatkan apresiasi setinggitingginya. Bukan jemaat, bukan khotbah yang baik, bukan bagaimana mengatur organisasi gereja yang bagus, tetapi kesejahteraan dan kehidupan kerohanian keluarga harus tetap dinomorsatukan. Dengan demikian maka tidak akan ada penyesalan pada akhir hidup kita karena kita telah gagal membimbing keluarga untuk hidup dalam Tuhan. ${ }^{24}$

\section{Peran Sebagai Pelayan}

24 Thomas Curtis, ..., 40. 
Dalam Markus 10:45 Tuhan Yesus mengatakan: "Karena Anak Manusia juga datang bukan untuk dilayani, melainkan untuk melayani dan menyerahkan nyawa-Nya menjadi tebusan bagi banyak orang”. Pernyataan ini mengandung makna ganda. (1) Dia datang untuk melayani (bukan untuk dilayani) dan (2) Pelayanan itu memerlukan pengorbanan (meski harus menyerahkan nyawa sekalipun). Inilah inti pekerjaan Tuhan Yesus. Keteladanan seperti itulah yang dibutuhkan oleh seorang pemimpin. Tuhan Yesus menghabiskan masa pelayanan-Nya yang tiga setengah tahun itu hanya untuk pelayanan. Lebih lanjut Tuhan Yesus juga mengatakan, “ Barangsiapa terbesar di antara kamu, hendaklah ia menjadi pelayanmu ..." (Matius 23:11). Berkaitan dengan ini Myron Rush ${ }^{25}$ mengatakan bahwa "seorang pemimpin yang baik haruslah juga seorang pelayan yang baik" Lebih lanjut Rush menambahkan bahwa seorang pemimpin seakan-akan berada di persimpangan jalan. Ada kerelaan untuk melayani atau justru minta untuk dilayani. ${ }^{26}$ Profil kepelayanan dan kepedulian gembala terhadap dombanya secara rinci dilukiskan oleh pemazmur dalam Mazmur 23.

Sebagaimana telah disebutkan di muka, pelayanan itu bersifat wholistik. (menyeluruh) yang menyangkut seluruh aspek kebutuhan manusia yang meliputi kebutuhan tubuh, jiwa dan roh sehingga perlu mendapatkan layanan yang sepadan. Hal itu dapat ditempuh dengan cara: mengajar (teaching) $\rightarrow$ jiwa; memberitakan (preaching) $\rightarrow$ roh dan menyembuhkan (healing) $\rightarrow$ tubuh (lihat Matius 9:35)., di antaranya dengan melakukan kunjungan atau visitasi.

\section{Kunjungan atau visitasi.}

Akar kata bahasa Ibrani untuk visitasi adalah paqad atau yang dalam bahasa Gerika adalah episkopeo, episkeptomai. Sedangkan kata visitation (visitasi) itu sendiri diambil langsung dari bahasa Latin visitare yang semula berarti mengunjungi: (a) untuk menguji dengan mengadakan tes, dan (b) untuk melihat apakah semua sudah berjalan sebagaimana mestinya. Sumner Wemp

${ }_{25}$ Myron Rush. The New Leader: A Revolutionary Approach to Effective Leadership. (Wheathon, IL., Victor Books: 1989), 79

${ }^{26} \mathrm{Ibid}, 81$. 
menjelaskan bahwa visitasi artinya pergi untuk mengunjungi seseorang dan memberikan bantuan kepadanya (going to see someone and to help them). Dalam visitasi ini ada pelayanan yang khusus, one to one, face to face (bandingkan dengan prinsip pendekatan dalam konseling) dan ada dialog. Lebih lanjut Sumner Wemp mengatakan: "Visitation is the missing link between the pulpit and the people."27 Visitasi bisa mengisi kekosongan/ kepincangan yang terjadi antara "mimbar" dan jemaat. Apa yang tidak bisa diperoleh melalui mimbar, bisa diperoleh melalui perkunjungan. Kebanyakan pendeta saat ini hanya mengunjungi jemaat yang sakit, yang sedang menghadapi masalah. Sumner Wemp kembali mengingatkan agar “... jangan terlalu berharap agar orang lain untuk masuk ke gereja Anda, tanpa terlebih dahulu Anda mau mengunjunginya." 28 Visitasi memang sangat alkitabiah. Sebagaimana "tuan" yang mengutus para hambanya untuk mengundang siapa saja yang ditemui agar memenuhi ruangan/rumah pestanya (Lukas 14:23). Rasul Paulus juga memiliki visi seperti ini, sebagaimana dikatakannya: "Sungguhpun demikian aku tidak pernah melalaikan apa yang berguna bagi kamu. Semua kuberitakan dan kuajarkan kepada kamu, baik di muka umum maupun dalam perkumpulan-perkumpulan di rumah kamu." (Kisah Para Rasul 20:20). Jadi jelas, bahwa visitasi itu sangat penting. "A homegoing pastorproduces a churchgoing people," kata Sumner Wemp. ${ }^{29}$ Jika Pendeta mau mengunjungi jemaatnya maka sebaliknya jemaat juga akan ganti mau mengunjungi gereja. Karena itu tak ada cara lain yang lebih baik untuk bisa mengenal jemaat secara lebih dekat, kecuali harus mengunjungi mereka. ${ }^{30}$

\section{Tujuan visitasi}

Seringkali orang memiliki anggapan yang salah terhadap maksud visitasi. Ada yang beranggapan bahwa tujuan visitasi adalah agar gereja menjadi penuh, atau gereja menjadi semakin kudus. Tetapi Maria Bons-Storm

${ }^{27}$ C. Sumner Wemp. The Guide to Practical Pastoring. (Nashville-Camden-New York: Thomas Nelson Publishers, 1982), 73.
${ }^{28}$ Ibid., 74.
${ }^{29}$ Ibid. 74
${ }^{30}$ Ibid. 76 
mengatakan bahwa visitasi atau perkunjungan itu bertujuan (1) mencari dan mengunjungi anggota jemaat satu persatu, (2) mengabarkan firman Allah kepada mereka, dalam situasi hidup mereka pribadi, (3) melayani mereka, sama seperti Tuhan Yesus melayani mereka dan (4) supaya mereka lebih menyadari iman mereka, dan dapat mewujudkan iman itu dalam hidupnya sehari-hari. Atau dengan kata lain, agar jemaat itu dibangunkan imannya. ${ }^{31}$

\section{Peran Sebagai Pengkhotbah}

Khotbah bukanlah satu-satunya tugas yang dikerjakan oleh seorang gembala/pemimpin gereja. Tetapi khotbah merupakan bagian yang paling penting dalam pelayanan seorang hamba Tuhan. Seorang pengkhotbah besar tidak hanya mau berkhotbah di tempat-tempat dan gereja-gereja yang besar saja, tetapi juga tetap bersedia berkhotbah meskipun di tempat yang kecil. Secara garis besar Willimon dan Wilson. ${ }^{32}$ dalam tulisannya menyebutkan bahwa seorang pengkhotbah itu dikatakan besar apabila: (1) banyak pendengar yang datang dan tertarik, (2) melakukan perkara-perkara besar yang membangun orang lain; (3) bisa menciptakan kreativitas dan (4) meskipun sedikit orang, tetapi tetap mau berkhotbah. Anderson ${ }^{33}$ menambahkan (5) seorang gembala sebaiknya tidak memberikan pelayanan mimbarnya sendiri kepada orang lain sementara ia pergi berkhotbah ke tempat lain.

\section{Pelayan/Gembala selaku Pemberita Firman}

Tugas utama seorang pelayan atau gembala adalah untuk berkhotbah atau memberitakan firman Tuhan. Dalam berkhotbah, seorang hamba Tuhan sebenarnya sedang mewakili Allah untuk berbicara kepada umat-Nya. Dalam khotbah, ia menyampaikan satu kerygma, yaitu firman Allah yang diberitakan (The proclaimed word of God) harus berpusat pada Tuhan Yesus sendiri sebagai firman yang telah menjadi daging (the incarnated word of God

${ }^{31}$ M. Bons-Storm Apakah Penggembalaan Itu?: Petunjuk Praktis untuk Pelayanan Pastoral. (Jakarta: BPK Gunung Mulia, 1993), . 23 dan 26.

32 William H. Willimon \&Robert L. Wilson. Preaching and Worship in the Small Church (Nashville: Abingdon Press, 1980) 103

33 Robert Anderson, Ibid, , 186. 
dan hanya bersumber dari Alkitab sebagai firman yang tertulis (the written word of God) yang bisa diampaikan dalam bentuk:

Khotbah Pastoral: (1) memberi makan domba, (2) melihat kebutuhan domba, (3) melindungi mereka dari ajaran sesat $\rightarrow$ harus memberitakan doktrin yang tepat/benar. Untuk bisa memenuhi kebutuhan jemaat, khotbah mingguan sebaiknya dibuat secara terencana, oleh pendeta/gembala sendiri dan usahakan agar jangan terlalu banyak mengundang pengkhotbah dari luar. Karena gembala seharusnya paling banyak tahu tentang keadaan dan kebutuhan domba-dombanya. Khotbah yang terencana (dengan topik-topik tertentu) akan memerkaya kerohanian jemaat dan pertumbuhan iman mereka. Khotbah yang terencana sesuai topik itu misalnya: ${ }^{34}$

(a) Minggu pertama: khotbah penginjilan

(b) Minggu kedua : khotbah doktrinal

(c) Minggu ketiga : khotbah pertumbuhan (iman)

(d) Minggu keempat: khotbah tentang kehidupan sehari-hari (masalah pergumulan hidup, dsb.).

Atau bisa juga khotbah-khotbah lain yang bertemakan etika/moral, persembahan, pelayanan, doa, dsb.

Euangelizomai: khotbah penginjilan, yaitu khotbah-khotbah yang bersifat ajakan atau pemberitaan agar pendengar percaya serta menerima Tuhan Yesus sebagai Juruselamat pribadinya. Khotbah ini haruslah khotbah yang bisa menggerakkan, disertai dengan ilustrasi-ilustrai menarik. Tujuannya adalah agar pendengar seakan-akan melihat atau mengalami sendiri peristiwa yang diuraikan dalam khotbah. Misalnya khotbah tentang anak yang hilang (Lukas 15:1-7); domba yang sesat (Lukas 15:1-7); orang kaya dan Lazarus yang miskin (Lukas 16:19-31); orang kaya yang bodoh (Lukas 12:13-21); tentang ajakan Juruselamat (Matius 11:28); pengajaran akhir zaman (Matius 24-25) dsb. Yang harus diperhatikan dalam khotbah jenis ini adalah:

${ }^{34}$ Martin Thielen. Getting Ready for Sunday: A Practical Guide for Worship Planning (Broadman Press, Nashville, Tennessee: 1989), 16 ff. 
- Pendengar : kita harus tahu bahwa mereka itu mungkin adalah orangorang yang masih “tersesat". Mereka kebanyakan juga kurang minat, sehingga harus dibuat berminat.

- Oleh karena itu pembahasan Alkitab jangan terlalu bertele-tele dan menggunakan istilah-istilah teologi yang sulit.

- Mereka bisa mengikuti jalan pikiran kita, asal poinnya sederhana.

- Sebaiknya khotbah jangan terlalu panjang, sehingga mereka tidak bosan.

- Sebisa mungkin gunakan banyak ilustrasi untuk menolong mereka memahami firman Tuhan.

Alkitab menunjukkan paling tidak ada 3 (tiga) tipe penginjilan yang berbeda, yaitu:

- Orang yang mencari kita, contoh: Nikodemus (Yohanes 3:1-21).

- Pertemuan yang terjadi secara kebetulan . Contoh: perempuan Samaria yang bertemu dengan Tuhan Yesus di tepi sumur (Yohanes 4:1-42).

- Menggunakan kesempatan yang ada atau kita yang mencari (Kisah Para Rasul 8:26-40).

Didaskalein: khotbah yang bersifat pengajaran. Misalnya khotbah yang berhubungan dengan masalah moral, keluarga, perkawinan, pekerjaan, pelayanan, dsb.

Khotbah-khotbah khusus, misalnya dikaitkan dengan

- Perayaan gerejawi seperti Natal, Paskah, Kenaikan, Pentakosta, dll.

- Hari-hari besar nasional, misalnya: Peringatan HUT Kemerdekaan, Hari Ibu, Harkitnas, Hardiknas dsb.

- Peristiwa-peristiwa khusus gerejawi, seperti: Hari Reformasi, HUT Gereja, Baptisan, dsb.

Khotbah-khotbah doktrinal (tentang surga dan neraka, akhir zaman, kematian, penghukuman, keselamatan, dsb.).

Keuntungan menyusun planning

- Terhadap jemaat: mereka akan tahu 
- Terhadap pendeta: tidak bingung, sistematis

- Terhadap pengerja yang lain, misalnya: liturgos, pemimpin koor dsb. bisa memilih lagu yang sesuai.

Terkait dengan soal berkhotbah, Curtis Thomas ${ }^{35}$ secara tegas menyampaikan kritik terhadap pengkhotbah yang dinilainya gagal dalam berkhotbah, dan ini terutama dikarenakan oleh:

- Sangat kurang atau bahkan mungkin tidak ada ilustrasi sama sekali, atau sebaliknya, terlalu banyak ilustrasi.

- Tidak ada poin atau sebaliknya terlalu banyak poin.

- Terlalu banyak waktu untuk menjelaskan eksegese yang tidak terlalu diperlukan.

- Tidak ada struktur dan urut-urutan yang jelas.

- Langsung masuk pada aplikasi.

- Tidak memakai catatan khotbah (minimal harus ada outline).

- Isi yang tidak seimbang (misalnya pendahuluan terlalu panjang, atau isi poin yang satu dengan lainnya yang tidak sama. Ada yang terlalu panjang, tapi ada yang terlalu pendek).

- Berupa kesaksian saja yang sering tidak berkaitan langsung dengan khotbah.

- Seringkali seperti berbicara terhadap diri sendiri atau hanya beberapa orang pendengar (seperti berbisik).

Tentang teori dan praktik pemberitaan firman keduanya dipelajari secara dalam hermeneutika dan homiletika.

Hal lain yang perlu diingat oleh para gembala adalah pelayananpelayanan yang lebih bersifat pribadi (misalnya undangan keluar), tukar

${ }^{35}$ Curtis C. Thomas. ..., $67 \mathrm{ff}$ 
mimbar, dsb. yang tidak boleh mengganggu atau mengorbankan pelayanan di gereja yang dilayani.

\section{Peran Sebagai Guru/Pengajar}

Seringkali tugas ini kurang mendapat perhatian para gembala/hamba Tuhan. Padahal Tuhan Yesus sendiri sebelum naik ke surga telah memberikan amanat yang sangat jelas, yaitu agar para murid itu itu pergi untuk: menjadikan semua bangsa murid-Nya, membaptis mereka dan mengajar mereka melakukan firman Tuhan (Mat. 28:19-20). Inilah yang juga menjadi ugas dan panggilan gereja, yaitu: (1) Marturia (kesaksian); (2) Koinonia (persekutuan); (3) Diakonia (pelyanan) dan (4) Didakhe (pengajaran). Dalam 1 Timotius 4:11 Rasul Paulus memberi perintah kepada Timotius untuk mengajar, di samping memberitakan. Dengan kata lain pemberitaan (firman) baru akan benar-benar menjadi lebih efektif apabila disertai dengan pengajaran. Norris W. Stoa ${ }^{36}$ dalam buku "Baker's Dictionary of Practical Theology” yang dieditori oleh Ralph G. Turnbull mencatat bahwa tugas-tugas kependetaan selaku pemimpin dan gembala jemaat paling tidak ada: (1) Menyampaikan pengajaran-pengajarannya kepada jemaat. Bukan sebagai seorang guru yang mengajar di kelas, tetapi yang mengajarkan tentang kebenaran-kebenaran firman Tuhan, yang bisa dilakukan sekaligus bersamaan dengan khotbahnya. (2) Secara lebih spesifik mengajar jemaat melalui pelajaran katekisasi. (3) Mengajar melalui kelompok bible studi (pemahaman/ penelaahan Alkitab). Hal ini merupakan cara yang lebih intensif dan terstruktur, sehingga dengan bahan-bahan yang lebih komprehensif itu akan membuat jemaat lebih berwawasan luas dalam cakrawala iman Kristen mereka.

Jemaat yang sudah mendapatkan pengajaran-pengajaran secara lebih baik dan mendalam akan lebih mampu bertahan dalam menghadapi pengaruh-pengaruh atau pengajaran dari luar yang bertentangan dengan kebenaran.

36 Ralph G. Turnbull. Baker's Dictionary of Practical Theology. (Grand Rapids, MI.: Baker's Books House, 1976) ..., 322-323. 


\section{Peran Sebagai Administrator}

Sebelum membahas ini lebih lanjut, sebaiknya perlu dipahami, bahwa yang dimaksud dengan administrator itu bukan berarti harus melakukan tugas "keadministrasian", melainkan lebih merujuk pada kemampuan seseorang dalam melaksanakan peran kepemimpinannya. Hanyalah pemimpin yang bodoh yang tidak pernah mau belajar dan memandang penting unsur administrasi. Dia tidak perlu menjadi pelaku, namun harus memahami sehingga dia tahu bagaimana administrasi yang baik itu. Karena dengan demikian barulah dia bisa meningkatkan mutu pelayanannya. Dalam hal ini termasuk di dalamnya adalah fungsi pembinaan dan supervisi.

Dengan memahami ini seorang pemimpin akan dapat meningkatkan pembinaan staf, etos kerja yang baik dan kondusif serta membangun dasar berorganisasi yang kokoh. ${ }^{37}$ Karena itu mempelajari prinsip-prinsip organisasi dan administrasi secara tepat akan semakin meningkatkan mutu kepemimpinan dan pembinaan warga gereja. Adalah salah apabila seorang pendeta melakukan segala sesuatu sendiri. Tetapi juga akan salah apabila segala sesuatu tidak diketahuinya dan hanya diserahkan kepada orang lain. Bahkan menurut Anderson ${ }^{38}$ terhadap masalah yang sensitif, seperti masalah keuangan pun, seorang pendeta harus bisa mengontrol dan memanej. Dia tidak boleh tidak mau tahu tentang keuangan gereja. Tetapi juga tidak boleh terlalu campur tangan dengan masalah keuangan gereja terlalu dalam. Yang penting, dengan mengetahui jumlah serta posisi keuangan, seorang pemimpin gereja/hamba Tuhan akan bisa melihat program mana yang bisa dijadikan prioritas. Tetapi sebaliknya Ernest O. White ${ }^{39}$ mengingatkan agar jangan sampai organisasi itu dijadikan sebagai berhala. Semua harus sempurna. Lalu seluruh pekerjaan atau pelayanan hanya dikonsentrasikan kepada masalah-masalah organisasi. Ini sangat berbahaya.

37 Ibid, . 314-315.

38 Robert C. Anderson, ..., 278

39 Ernest O. White, Becoming a Christian Leader. (Nashville, Tinnessee: Convention Press, 1985) . 70-71 


\section{Peran Sebagai Motivator}

Kita tidak boleh hanya mengatakan: "semua terserah Tuhan" atau "mau apa lagi?" dengan dalih merohanikan segala sesuatu dan seakan-akan mau melegalkan semua yang kita lakukan. Sekali lagi di sini Anderson ${ }^{40}$ menegaskan bahwa seorang pemimpin mutlak harus bertindak aktif (bahkan proaktif) untuk kemajuan dan pengembangan gereja melalui kepemimpinannya. Ia harus bisa memotivasi warga jemaat, khususnya para pengurus gereja/majelis dan hamba Tuhan lainnya untuk bisa berperan aktif. Karena itu biasakan untuk mendengarkan, menyeleksi dan menerima yang baik aspirasi mereka. Berikan peluang kepada mereka untuk bisa berbuat dan memilih apa yang terbaik untuk bisa dilakukan yang sesuai dengan arah kebijakan gereja.

Dalam hal ini pemimpin harus bisa memberikan teladan, tidak asal main tunjuk dan memberikan perintah. Dia bukanlah bos di gereja, melainkan juga seorang pelayan. Bisa menggali potensi atau sumber daya manusia dalam gereja atau orang-orang yang dipimpinnya. Yang ragu-ragu atau merasa tidak sanggup untuk berbuat atau melakukan sesuatu, perlu didorong dan dimotivasi. Yang mampu tetapi tidak mau, juga perlu didorong dan diberi pengertian/kesadaran.

\section{Memenuhi kebutuhan dan memaksimalkan kemampuan orang lain}

Myron Rush ${ }^{41}$ dalam bukunya "The New Leader" di bawah judul "The Art of Motivating Others" menuliskan bahwa mustahil kita bisa memotivasi seseorang apabila kita tidak bisa menetapkan tujuan yang bisa memuaskan kebutuhan mereka serta tidak memanfaatkan kemampuan mereka secara optimal. Siapa pun ingin dihargai, sekaligus ingin agar kebutuhannya terpenuhi (bandingkan dengan hirarki dalam teori kebutuhan dasar manusia menurut Maslow). Iklim kerjasama yang baik, akan mendatangkan hasil yang baik. Tetapi yang perlu diingat adalah bahwa "semua itu dari semua-oleh karena anugerah Tuhan_-dan untuk semua”. Kebaikan, keberhasilan dan

\footnotetext{
40 Robert Anderson, Ibid. . 348 dyb

41 Myron Rush. The New Leader. (Wheaton, Illinois: Victor Books, 1982) . 107
} 
kemajuan gereja bukan karena pemimpin/ pendeta/hamba Tuhan atau pengurus/majelis atau oleh sekelompok orang, tetapi karena peran semua pihak. Ide pemimpin yang bagus, kerjasama yang baik tanpa dukungan seluruh jemaat atau anggota, hasilnya akan sia-sia. Karena itu keberhasilan juga harus menjadi milik bersama, kebanggaan bersama demi kemuliaan nama Tuhan.

\section{Peran Sebagai Inovator}

Pemimpin juga harus bisa menjadi seorang inovator. Tidak bijaksana kalau gereja atau jemaat, apalagi pemimpin, hanya berdiam diri untuk menikmati dan terus puas dengan apa yang sudah dilakukan/dicapainya. Pekerjaan Tuhan tidak boleh mandeg hanya karena kita merasa sudah mencapai target. Apalagi jikalau menganggap bahwa apa yang dikerjakan/ dicapai itu sudah yang terbaik. Hal ini akan berakibat tidak mau mengembangkan daya kreativitas untuk hal-hal yang lebih inovatif. Mungkin apa yang dianggap sudah sangat baik saat ini untuk tiga, lima atau sepuluh tahun mendatang sudah menjadi kurang baik atau tidak efisien.

\section{KESIMPULAN}

Tuntutan ideal jemaat terhadap hamba Tuhan sebagai pemimpin rohani sering menjadikan frustrasi. Hamba Tuhan dituntut untuk bisa melakukan apa saja dengan baik/sempurna. Hal ini sering menjadikan hamba Tuhan sebagai pemimpin dalam gereja serba sulit. Antara tuntutan dan kemampuan seringkali tidak seimbang. Repotnya sering ada hamba Tuhan yang sebenarnya tidak mampu tetapi menganggap dirinya serba bisa dan mampu sampai akhirnya melakukan segala sesuatu seorang diri. Ia mau menjadi One Man Show. Pada dasarnya orang seperti ini hanya ingin mendapatkan pujian. Dia tidak bisa dan tidak mau memercayai orang lain. Akibatnya segala sesuatu tergantung pada dirinya. Pekerjaan Tuhan malah terbengkelai. Tetapi kalau ada sesuatu yang tidak beres, dengan gampang akan menyalahkan orang lain, dan sebaliknya akan mengklaim keberhasilan itu sebagai hasil perjuangan dan jerih payahnya. Ini jelas keliru. Bagaimana pun, seorang hamba Tuhan harus berusaha untuk melakukan segala sesuatu 
dengan sebaik-baiknya disertai rasa tanggung jawab terhadap Tuhan dan yang dilayaninya. Untuk mengakhiri tulisan ini, saya kutip sebuah ayat dari 2Tawarikh 29:11, demikian bunyinya, "Anak-anakku, sekarang janganlah kamu lengah, karena kamu telah dipilih TUHAN untuk berdiri di hadapanNya untuk melayani Dia, untuk menyelenggarakan kebaktian dan membakar kurban bagi-Nya."

"Man is not what he thinks, man is not what he feels, man is not what he eats, man is not what he behaves, but man is what he reacts before God!" (Rev. Dr. Stephen Tong)

HADI P. SAHARDJO, menyelesaikan pendidikan teologinya di Seminari Alkitab Asia Tenggara, Malang (B.Th., S.Th., M.A. dan M.Div.) dan International Theological Seminary, ITS, Los Angeles, USA (Th.M.), serta D.Th. (Asian Baptist Graduation Theological Seminary/STBI Semarang). Gelar Drs. (Doktorandus) di bidang Psikologi Pendidikan dan Bimbingan Konseling dari IKIP (sekarang Universitas) Negeri Malang. Saat ini penulis menjadi dosen tetap dan Pembantu Ketua III/Bid. Kemahasiswaan/ Pelayanan di ST'T SAPPI. 